\title{
Detection of human papillomavirus DNA in gastric carcinoma specimens in a high-risk region of Iran
}

\author{
FARZANEH FAKHRAEI ${ }^{1}$, MOHAMMAD REZA HAGHSHENAS ${ }^{1}$, VAHID HOSSEINI ${ }^{2}$, \\ ALIREZA RAFIEI $^{1}{ }^{1}$ FARSHAD NAGHSHVAR $^{1}$ and REZA ALIZADEH-NAVAEI ${ }^{3}$ \\ ${ }^{1}$ Molecular and Cell Biology Research Center; ${ }^{2}$ Gastrointestinal and Liver Research Center; ${ }^{3}$ Gastrointestinal \\ Cancer Research Center, Mazandaran University of Medical Sciences, Sari, Mazandaran 48178-44718, Iran
}

Received March 30, 2016; Accepted July 7, 2016

DOI: $10.3892 /$ br.2016.728

\begin{abstract}
Gastric cancer is the fourth most common type of cancer worldwide and is associated with high mortality rates. The incidence of gastric cancer varies widely in different geographical regions. For example, in Iran, the most northern and northwestern regions are considered to be high-risk areas for gastric cancer. The aim of the present study was to determine the distribution of human papillomavirus (HPV) genotypes among patients with gastric carcinoma in Mazandaran province, Northern Iran, which is a high-risk area. A total of 100 paraffin-embedded tissue samples were obtained from 70 males and 30 females with gastric carcinoma, diagnosed between 2006 and 2013, in the Imam Khomeini Hospital (Sari, Iran). GP5+/GP6+ general primers were applied for detection of HPV DNA in the specimens. Positive samples were then selected and high-risk HPV genotyping was performed. The samples were analyzed by polymerase chain reaction and five $(5 \%)$ samples were identified to be positive for HPV DNA [four male $(5.7 \%)$ and one female $(3.3 \%)]$. Three $(60 \%)$ samples were positive for HPV-16, one (20\%) sample was positive for HPV-18 and one (20\%) sample was positive for HPV-45. Following pathological diagnosis, 88 samples were identified as gastric adenocarcinoma, nine samples were gastric lymphoma, and three samples were gastric and esophagus adenocarcinoma. According to the findings of the present study and the rate of HPV infection in patients with gastric carcinoma, an association between HPV infection and gastric carcinoma in subjects from Northern Iran was not identified.
\end{abstract}

Correspondence to: Dr Mohammad Reza Haghshenas, Molecular and Cell Biology Research Center, Mazandaran University of Medical Sciences, Km 17 Khazarabad Road, Sari, Mazandaran 48178-44718, Iran

E-mail: haghshenas2001@yahoo.com

Key words: gastric carcinoma, human papillomavirus, HPV genotyping, high-risk HPV

\section{Introduction}

Gastric cancer is one of the most common types of cancer and is a leading cause of cancer-associated mortality in the world (1). Approximately 22,220 patients are diagnosed annually in the United States, of whom 10,990 are expected to succumb to the disease (2). Gastric cancer is more common in men than in women in developed and developing countries (3). Furthermore, the incidence of gastric cancer varies in different geographic regions. Rates are highest in Japan, Korea, China, Chile, Costa Rica and Brazil where the incidence is $>20$ per 100,000 person-years in men. The intermediate-risk areas are Italy, UK, Germany, the Netherlands and Turkey, and the low-risk areas are USA, Canada, Sweden, Denmark, Egypt, India and Australia (4,5). Comparative studies between Western and Asian countries demonstrate significant differences in the incidence and survival rates of gastric cancer; therefore, ethnicity is a possible risk factor (1). The most important and common cause of gastric cancer is excessive consumption of salt, smoking, long term subjection to nitrosamines in food and drinking water, as well as microbial infections, such as Helicobacter pylori and certain viruses, including the human papillomavirus (HPV) $(6,7)$. Helicobacter pylori causes chronic gastritis and progresses to atrophic gastritis, intestinal metaplasia, glandular dysplasia and eventually gastric carcinoma $(8,9)$.

HPVs are non-enveloped, circular, double-stranded and relatively small DNA tumor viruses with a genome of $\sim 8,000$ base pairs (10). These viruses infect cutaneous and mucosal epithelial tissues, which cause a wide variety of diseases from skin and anogenital warts to laryngeal papillomas and anogenital intraepithelial neoplasias, which often progress to malignancy (11). Thus far, >100 different types of HPV have been identified and certain strains of HPV are associated with different risk levels of the transformation into various types of human squamous cell carcinoma (12). HPV is classified into two groups: Mucosal infection HPVs and cutaneous infection HPVs. Each of these groups is divided into high and low risk $(12,13)$. The low-risk HPV types, such as HPV6 and HPV11 commonly cause benign warts and low grade premalignant lesions that regress and do not progress to cancer. The high-risk types of HPV, including HPV-16, -18, $-31,-33$ and -45 are associated with the development of certain 
mucosal epithelial cancers, such as cervical, anal, vulvar and penile cancer, as well as oral, laryngeal, esophageal and possibly gastric cancer $(14,15)$. It has been demonstrated that $\sim 20 \%$ of oral cancers, particularly oropharyngeal carcinoma in patients who do not use tobacco and alcohol (the most common risk factors) are also at high risk of being HPV-positive (16).

In Iran, the incidence of gastric cancer differs according to the risk level (high, intermediate or low). The northern and northwestern regions are high-risk areas for gastric cancer, whilst other geographical areas are intermediate and low risk. Possible environmental risk factors are proposed as a reason for this variation (5). A strong spatial clustering of gastric cancer in men and women is reported in the Mazandaran province (17). However, there is paucity of information regarding the prevalence of HPV in gastric cancer in the north of Iran and also around the world. The current study was designed to determine the distribution of HPV genotypes among patients with gastric carcinoma in Mazandaran province, northern Iran between 2006 and 2013, using polymerase chain reaction (PCR).

\section{Materials and methods}

Gastric cancer sample collection. A cross-sectional study was performed in which 100 paraffin-embedded tissue samples of gastric cancer were investigated. All samples were from patients that were diagnosed between 2006 and 2013 at the Imam Khomeini Hospital Infection Disease Center (Sari, Iran), which is in Mazandaran province, Northern Iran. The patients included 70 males and 30 females (mean age, $69.61 \pm 12.25$ years). A questionnaire was used to obtain further information regarding smoking habit, alcohol consumption, weight loss, family history of gastric cancer, anatomical sites of tumors, pathological diagnosis and metastasis.

Preparation of samples. Sections (thickness, 5-10 $\mu \mathrm{m}$ ) were collected in sterile micro tubes. To prevent cross-contamination, sharp blades were used and gloves were changed between each sample cutting. To deparaffinize the samples, the paraffin-embedded tissues were saturated in xylene (30 $\mathrm{min})$, then incubated in a graded ethanol series (1 $\mathrm{min}$ each) of $100 \%$ ethanol (dehydration) to $40 \%$ ethanol, then with double-distilled water for rehydration for $10 \mathrm{sec}$.

DNA extraction. DNA extraction was performed using a High Pure PCR Template Preparation kit (Roche Diagnostics $\mathrm{GmbH}$, Mannheim, Germany) according to the manufacturer's instructions. In brief, tissue lysis buffer [200 $\mu$ l; $4 \mathrm{M}$ urea, $200 \mathrm{mM}$ Tris, $20 \mathrm{mM} \mathrm{NaCl}$ and $200 \mathrm{mM}$ EDTA (pH 7.4)] and $40 \mu \mathrm{l}$ proteinase $\mathrm{K}$ were mixed and incubated overnight at $37^{\circ} \mathrm{C}$. The next day, $200 \mu \mathrm{l}$ binding buffer [ $6 \mathrm{M}$ guanidine- $\mathrm{HCl}$, $10 \mathrm{mM}$ urea, $10 \mathrm{mM}$ Tris-HCl, 20\% Triton X-100 (v/v); pH 4.4 $\left.\left(25^{\circ} \mathrm{C}\right)\right]$ was added to the tubes and vortexed for a few seconds. To elute the DNA, $200 \mu \mathrm{l}$ pre-warmed $\left(70^{\circ} \mathrm{C}\right)$ elution buffer, low salt $(10 \mathrm{mM}$ Tris buffer, $\mathrm{pH} 8.5 ; 40 \mathrm{ml})$ was added and the extracted DNA was stored at $-20^{\circ} \mathrm{C}$ until the PCR. DNA quality and the absence of PCR inhibitors in the samples were evaluated by PCR with $\beta$-actin primer serving as a housekeeping gene. Distilled water served as a negative control to monitor contamination during PCR (Table I).
Table I. Primer sequences.

\begin{tabular}{ll}
\hline Primer & \multicolumn{1}{c}{ Sequence (5' to $3^{\prime}$ ) } \\
\hline GP5+ & TTTGTTACTGTGGTAGATACTAC \\
GP6+ & GAAAAATAAACTGTAAATCATATT \\
$\beta$-actin (forward) & CTGCCGTTTTGCGTAGGAC \\
$\beta$-actin (reverse) & AGGCGTACAGGGATAGCAC \\
\hline
\end{tabular}

HPV detection and genotyping. General primers, GP5+ and GP6+, were used to amplify the $\mathrm{L}_{1}$ gene (Table I). PCR was performed using 1X PCR buffer (Invitrogen; Thermo Fisher Scientific, Inc., Waltham, MA, USA), $3 \mathrm{mM} \mathrm{MgCl}_{2}$ (Invitrogen; Thermo Fisher Scientific, Inc.), 0.2 mM dNTPs, 0.5 U Taq DNA polymerase (Invitrogen; Thermo Fisher Scientific, Inc.), 25 pmol each primer, $500 \mathrm{ng}$ genomic DNA and sterile distilled water to a final volume of $25 \mu \mathrm{l}$. DNA was first denatured for 5 min at $94^{\circ} \mathrm{C}$ and 40 cycles of the following were performed: Denaturation for $1 \mathrm{~min}$ at $94^{\circ} \mathrm{C}$, annealing for $1 \mathrm{~min}$ at $48^{\circ} \mathrm{C}$ and elongation for $1 \mathrm{~min}$ at $72^{\circ} \mathrm{C}$. An additional cycle was also performed for 10 min at $72^{\circ} \mathrm{C}$. The HPV positive control was the HeLa cell line (HPV-18 positive). Finally, $10 \mu \mathrm{l}$ of each PCR product was analyzed by $2 \%$ agarose gel electrophoresis $(90 \mathrm{~V}$, 30-40 min). A HPV HCR genotype-EPh PCR kit (Amplisens, Voisins-le-Bretonneux, France) was used to determine the HPV genotype in positive samples. A total of 12 high-risk HPV genotypes, specifically $16,18,31,33,35,39,45,52,56,58,59$ and 66 , were examined. PCR amplification for detection of the $12 \mathrm{HPV}$ genotypes was run in three tubes. HPV-positive and -negative samples were included for each sample that was run.

Gel electrophoresis. To determine the HPV genotypes, PCR products were examined by $1.5 \%$ agarose gel electrophoresis. All of the amplified products were different lengths, therefore, genotypes of the virus were analyzed by electrophoresis and visualized by an ultraviolet light trans-illuminator. Bands of appropriate size were identified by comparison with DNA molecular weight markers, which are a set of known DNA fragments. The adequacy of the DNA in each specimen for PCR amplification was determined by detection of the $\beta$-actin gene.

Statistical analysis. The $\chi^{2}$ test and Fisher's exact test were performed to determine the association between the presence of HPV DNA and smoking habit, alcohol consumption, weight loss, family history, anatomical site of tumor, pathological diagnosis, and metastasis. SPSS software (version 14; SPSS, Inc., Chicago, IL, USA) was used for the analyses. $\mathrm{P}<0.05$ was considered to indicate a statistically significant difference.

\section{Results}

Demographic findings. The positive rate of HPV DNA in the specimens was 5\% [4 men (5.7\%) and 1 woman (3.3\%)], which indicated no significant difference $(\mathrm{P}=1.000)$ between genders for HPV infection.

Genotype findings and clinicopathological factors. Gel electrophoresis results for HPV and high-risk HPV types obtained 
Table II. Association between virus genotypes and anatomical site of the tumor.

\begin{tabular}{lcccc}
\hline $\begin{array}{l}\text { Human papillomavirus } \\
\text { genotype }\end{array}$ & $\begin{array}{c}\text { Cardia, } \\
\mathrm{n}(\%)\end{array}$ & $\begin{array}{c}\text { Body of stomach, } \\
\mathrm{n}(\%)\end{array}$ & $\begin{array}{c}\text { Upper stomach and } \\
\text { lower third of esophagus, n (\%) }\end{array}$ & $\begin{array}{l}\text { Total, } \\
\mathrm{n}(\%)\end{array}$ \\
\hline 16 & $2(40)$ & - & $1(20)$ & $3(60)$ \\
18 & - & $1(20)$ & - & $1(20)$ \\
45 & - & - & $1(20)$ & $1(20)$ \\
Total & $2(40)$ & $1(20)$ & $2(40)$ & $5(100)$ \\
\hline
\end{tabular}
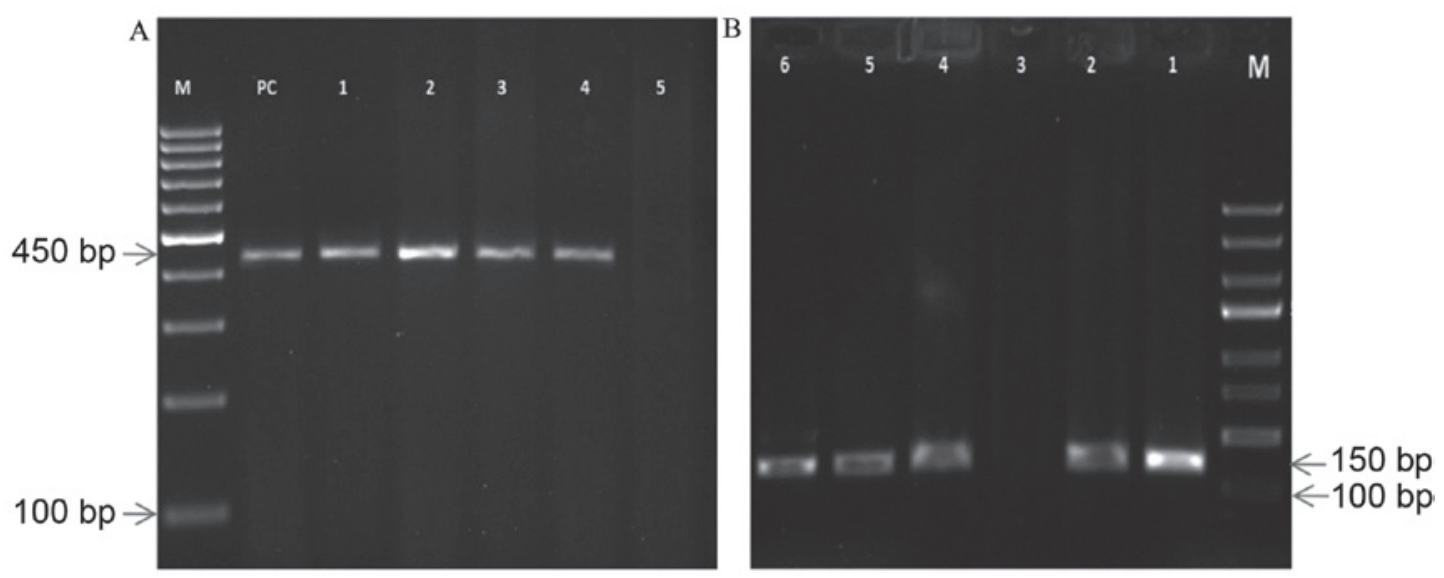

Figure 1. Gel electrophoresis pattern of HPV using specific primer amplification. (A) Lane M, DNA ladder (100 bp); lane PC, human DNA (450 bp); lanes 1-4, positive clinical samples of DNA extraction (450 bp); lane 5, negative sample. (B) Lane M, DNA ladder (100 bp); lane 1, HPV DNA (PC; 150 bp); lanes 2 and 4-6, positive clinical samples of HPV (150 bp); lane 3, negative sample. HPV, human papillomavirus; PC, positive control.

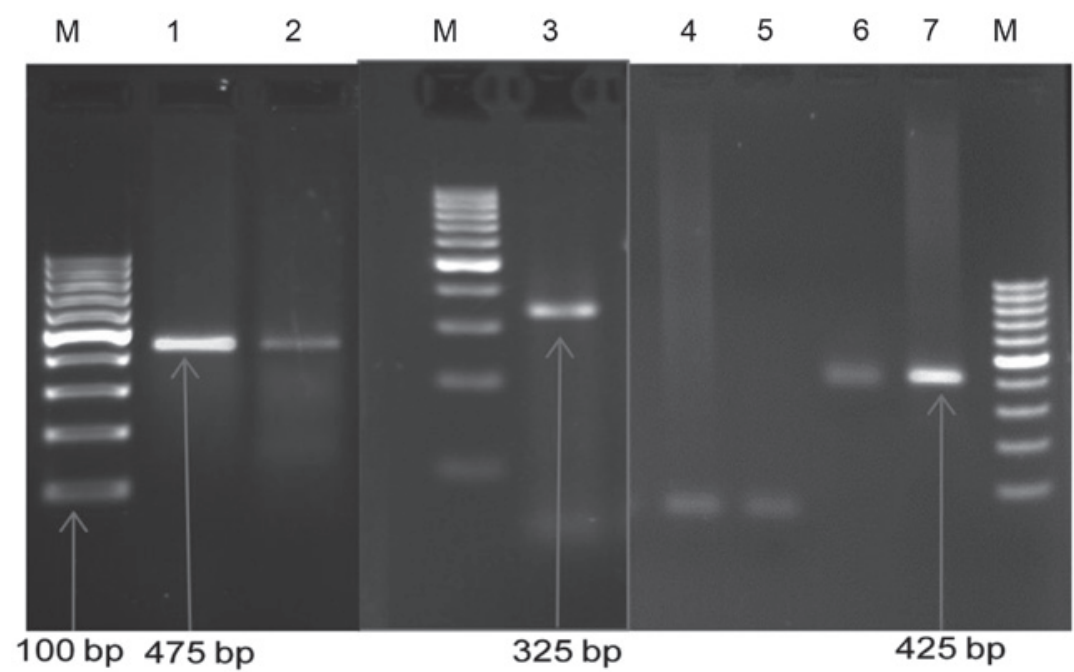

Figure 2. Gel electrophoresis pattern of high-risk HPV types using specific primer amplification. Lane M, DNA ladder (100 bp); lane 1, DNA HPV type 45 (PC; 475 bp); lane 2, positive sample DNA HPV type 45 (475 bp); lane 3, positive sample DNA HPV type 16 (325 bp); lanes 4 and 5, negative control; lane 6, DNA HPV type 18 (PC; 425 bp); lane 7, positive sample DNA HPV type 18 (425 bp). HPV, human papillomavirus; PC, positive control.

using specific primer amplification are shown in Figs. 1 and 2, respectively. HPV-16, -18 and -45 were detected in $5(5 \%)$ of the HPV-positive samples (Table II). The 100 samples were classified into three groups based on the pathological diagnosis: 88 Samples were gastric adenocarcinoma, 9 were gastric lymphoma and 3 were gastric and esophagus adenocarcinoma (Table III). Based on the location of the tumor there were three groups of samples: 35 Samples were from the cardia, 62 samples were from the body of the stomach, and three samples were from the lower third of the esophagus and upper stomach. The HPV infection was identified in different anatomical locations of the stomach as follows: Two (40\%) cases were positive in the cardiac region, one $(20 \%)$ case was positive in the body of the stomach and two (40\%) cases of 
Table III. Frequency of HPV infection based on pathological diagnosis.

\begin{tabular}{lccrr}
\hline HPV infection & Gastric adenocarcinoma & Gastric lymphoma & Gastric and esophageal adenocarcinoma & Total \\
\hline Yes & 3 & 0 & 5 & 9 \\
No & 85 & 9 & 1 & 95 \\
Total & 88 & 9 & 3 & 100 \\
\hline
\end{tabular}

HPV, human papillomavirus.

Table IV. Association between HPV infection and clinicopathological and demographic factors in patients.

\begin{tabular}{|c|c|c|c|c|}
\hline Factor & $\begin{array}{l}\text { Total, } \\
\mathrm{n}(\%)\end{array}$ & $\begin{array}{c}\text { HPV-negative, } \\
\text { n }(\%)\end{array}$ & $\begin{array}{l}\text { HPV-positive, } \\
\text { n }(\%)\end{array}$ & $\begin{array}{c}\text { P-value }\left(\chi^{2} \text { or }\right. \\
\text { Fisher's exact test })\end{array}$ \\
\hline Gender & & & & 1.000 \\
\hline Male & $70(70)$ & $66 / 70(94.3)$ & $4 / 70(5.7)$ & \\
\hline Female & $30(30)$ & 29/30 (96.7) & $1 / 30(3.3)$ & \\
\hline Location of tumor & & & & $<0.001$ \\
\hline Cardia & $35(35)$ & $33 / 35(94.3)$ & $2 / 35(5.7)$ & \\
\hline Body of stomach & $62(62)$ & $61 / 62(98.4)$ & $1 / 62(1.6)$ & \\
\hline $\begin{array}{l}\text { Lower third of esophagus } \\
\text { and upper stomach }\end{array}$ & $3(3)$ & $1 / 3(33.3)$ & $2 / 3(66.7)$ & \\
\hline Histology & & & & $<0.001$ \\
\hline Gastric adenocarcinoma & $88(88)$ & 85/88 (96.6) & $3 / 88(3.4)$ & \\
\hline Gastric lymphoma & $9(9)$ & 9/9 (100.0) & $0 / 9(0.0)$ & \\
\hline $\begin{array}{l}\text { Esophagus and } \\
\text { gastric adenocarcinoma }\end{array}$ & $3(3)$ & $1 / 3(33.3)$ & $2 / 3(66.7)$ & \\
\hline Weight & & & & 0.583 \\
\hline Weight loss & $78(78)$ & 73/78 (93.6) & $5 / 78(6.4)$ & \\
\hline No weight loss & $22(22)$ & $22 / 22(100.0)$ & $0 / 22(0.0)$ & \\
\hline Smoking & & & & 0.669 \\
\hline Smoker & $48(48)$ & $45 / 48(93.8)$ & $3 / 48(6.3)$ & \\
\hline Non smoker & $52(52)$ & $50 / 52(96.2)$ & $2 / 52(3.8)$ & \\
\hline Alcohol usage & & & & 1.000 \\
\hline Alcohol use & $16(16)$ & $15 / 16(93.8)$ & $1 / 16(6.3)$ & \\
\hline No alcohol use & $84(84)$ & $80 / 84(95.2)$ & $4 / 84(4.8)$ & \\
\hline $\begin{array}{l}\text { Family history } \\
\text { of gastric cancer }\end{array}$ & & & & 0.068 \\
\hline Yes & $57(57)$ & $52 / 57(91.2)$ & $5 / 57(8.8)$ & \\
\hline No & $43(43)$ & $43 / 43(100)$ & $0 / 43(0.0)$ & \\
\hline Metastasis & & & & 0.007 \\
\hline Positive & $38(38)$ & $33 / 38(86.8)$ & $5 / 38(13.2)$ & \\
\hline Negative & $62(62)$ & $62 / 62(100.0)$ & $0 / 62(0.0)$ & \\
\hline
\end{tabular}

HPV, human papillomavirus.

patients whose upper stomach and lower esophagus were also involved were positive for HPV DNA. The rate of infection with HPV in patients with gastric cancer who were smokers was $6.3 \%$, and there was a significant association of HPV infection with tumor location, tumor histology and metastasis (Table IV).

\section{Discussion}

In the present study, the rate of HPV infection in 70 males and 30 females was 5.7 and $3.3 \%$, respectively. No significant association was found between gender and HPV infection. HPV DNA was identified in 5\% of tumor tissue samples using 
GP5+/GP6+ consensus primers. HPV-positive DNA samples were further typed and HPV-16, -18 and -45 were identified.

In previous studies from China, differing results were obtained. Koshiol et al (18) proposed that the gastric cardiac region is not a target for HPV-induced carcinogenesis. However, HPV-16 was the most common type identified in the upper digestive tract in a study reported by $\mathrm{Xu}$ et al (7). In addition, Yuan et al (19) did not detect HPV in gastric cancer in China. Erol et al (20) investigated 106 gastric cancer samples and identified HPV DNA in 33 cases. The difference in the results among studies indicates the requirement for further investigations. In the present study, based on pathological diagnosis, HPV infection was observed in gastric adenocarcinoma (3\%), and in gastric and esophagus adenocarcinoma together (2\%). All gastric lymphomas were negative. Based on the anatomical site of the tumor, the rates of HPV infection were $40 \%$ in the cardiac region, $20 \%$ in the body of stomach and $40 \%$ in the upper stomach and lower third of esophagus. To the best of our knowledge, categorization based on anatomical sites, has not been conducted previously. Three cases in the present study were patients who presented with esophagus and gastric adenocarcinoma, and with adenocarcinoma of the lower third of the esophagus and the upper stomach together. According to our results, the HPV-positive percentage in these cases was higher. In conclusion, the question remains as to whether the infection of gastric cancer samples is affecting virus migration from the esophagus to the stomach. Few studies have been conducted on this topic globally, and the existing results are not conclusive. Furthermore, the association between HPV and gastric cancer cannot be confirmed with the present results and further investigations are required.

\section{Acknowledgements}

The present study was supported by the Vice-Chancellor for research of Mazandaran University of Medical Sciences (grant no. 90-96). The authors would like to thank the co-workers of the research groups in the Faculty of Medicine.

\section{References}

1. Konturek PC, Konturek SJ and Brzozowski T: Gastric cancer and Helicobacter pylori infection. J Physiol Pharmacol 57 (Suppl 3): 51-65, 2006.

2. Siegel R, Ma J, Zou Z and Jemal A: Cancer statistics, 2014. CA Cancer J Clin 64: 9-29, 2014.

3. No authors listed: Surveillance, epidemiology, and end results: Incidence and mortality data, 1973-77. Natl Cancer Inst Monogr 57: 1-1082, 1981.

4. Curado MP, Edwards B, Shin HR, Storm H, Ferlay J, Heanue M and Boyle P (eds): Cancer incidence in five continents, Vol. IX. IARC, Lyon, 2007.
5. Malekzadeh R, Derakhshan MH and Malekzadeh Z: Gastric cancer in Iran: Epidemiology and risk factors. Arch Iran Med 12: 576-583, 2009.

6. Backert S, Schwarz T, Miehlke S, Kirsch C, Sommer C, Kwok T, Gerhard M, Goebel UB, Lehn N, Koenig W, et al: Functional analysis of the cag pathogenicity island in Helicobacter pylori isolates from patients with gastritis, peptic ulcer, and gastric cancer. Infect Immun 72: 1043-1056, 2004.

7. Xu WG, Zhang LJ, Lu ZM, Li JY, Ke Y and Xu GW: Detection of human papillomavirus type $16 \mathrm{E} 6$ mRNA in carcinomas of upper digestive tract. Zhonghua Yi Xue Za Zhi 83: 1910-1914, 2003 (In Chinese).

8. Correa P, Haenszel W, Cuello C, Tannenbaum S and Archer M: A model for gastric cancer epidemiology. Lancet 2: 58-60, 1975.

9. Uemura N, Okamoto S, YamamotoS, Matsumura N, Yamaguchi S, Yamakido M, Taniyama K, Sasaki N and Schlemper RJ: Helicobacter pylori infection and the development of gastric cancer. N Engl J Med 345: 784-789, 2001.

10. Münger K, Baldwin A, Edwards KM, Hayakawa H, Nguyen CL, Owens M, Grace M and Huh K: Mechanisms of human papillomavirus-induced oncogenesis. J Virol 78: 11451-11460, 2004.

11. Walboomers JM, Jacobs MV, Manos MM, Bosch FX, Kummer JA, Shah KV, Snijders PJ, Peto J, Meijer CJ and Muñoz N: Human papillomavirus is a necessary cause of invasive cervical cancer worldwide. J Pathol 189: 12-19, 1999.

12. Muñoz N, Bosch FX, de Sanjosé S, Herrero R, Castellsagué X, Shah KV, Snijders PJ and Meijer CJ; International Agency for Research on Cancer Multicenter Cervical Cancer Study Group: Epidemiologic classification of human papillomavirus types associated with cervical cancer. N Engl J Med 348: 518-527, 2003.

13. de Villiers EM, Fauquet C, Broker TR, Bernard HU and zur Hausen H: Classification of papillomaviruses. Virology 324: 17-27, 2004.

14. Cañadas MP, Bosch FX, Junquera ML, Ejarque M, Font R, Ordoñez E and de Sanjosé S: Concordance of prevalence of human papillomavirus DNA in anogenital and oral infections in a high-risk population. J Clin Microbiol 42: 1330-1332, 2004.

15. de Sanjosé S and Palefsky J: Cervical and anal HPV infections in HIV positive women and men. Virus Res 89: 201-211, 2002.

16. Gillison ML, Koch WM, Capone RB, Spafford M, Westra WH, Wu L, Zahurak ML, Daniel RW, Viglione M, Symer DE, et al: Evidence for a causal association between human papillomavirus and a subset of head and neck cancers. J Natl Cancer Inst 92: 709-720, 2000.

17. Mohebbi M, Mahmoodi M, Wolfe R, Nourijelyani K, Mohammad K, Zeraati $\mathrm{H}$ and Fotouhi A: Geographical spread of gastrointestinal tract cancer incidence in the Caspian Sea region of Iran: Spatial analysis of cancer registry data. BMC Cancer 8: $137,2008$.

18. Koshiol J, Wei WQ, Kreimer AR, Ren JS, Gravitt P, Chen W, Kim E, Abnet CC, Zhang Y, Kamangar F, et al: The gastric cardia is not a target for human papillomavirus-induced carcinogenesis. Cancer Epidemiol Biomarkers Prev 19: 1137-1139, 2010.

19. Yuan XY, Wang MY, Wang XY, Chang AY and Li J: Non-detection of Epstein-Barr virus and Human Papillomavirus in a region of high gastric cancer risk indicates a lack of a role for these viruses in gastric carcinomas. Genet Mol Biol 36: 183-184, 2013.

20. Erol D, Bulut Y, Yüce H and Ozercan IH: Investigation of the presence of human papillomavirus DNA in various gastrointestinal carcinoma samples. Mikrobiyol Bul 43: 259-268, 2009 (In Turkish). 